\title{
Vibrio parahaemolyticus and V. harveyi cause detachment of the epithelium from the midgut trunk of the penaeid shrimp Sicyonia ingentis
}

\author{
Gary G. Martin*, Nicole Rubin, Erica Swanson \\ Department of Biology, Occidental College, Los Angeles, California 90041, USA
}

\begin{abstract}
Shrimp Sicyonia ingentis were either injected with Vibrio parahaemolyticus $\left(10^{4} \mathrm{CFU}\right)$ or $V$. harveyi $\left(10^{6} \mathrm{CFU}\right)$ or immersed in ASW containing either species at $10^{5} \mathrm{CFU} \mathrm{ml}^{-1}$. These densities were shown in preliminary experiments to kill approximately half the population by $7 \mathrm{~d}$. On Day 7, surviving shrimp were classified as either diseased or apparently healthy, and their midgut trunks (MGT) were examined by light and electron microscopy. All shrimp immersed in ASW containing either species of Vibrio showed detachment of the epithelium in the MGT. In shrimp injected with either species of Vibrio, epithelial detachment was common in diseased shrimp but not in apparently healthy animals. Experiments with live shrimp were supported by in vitro experiments where MGTs were removed, tied off at both ends, and injected with either pathogenic bacteria ( $V$. parahaemolyticus or $V$. harveyi), non-pathogenic bacteria (Bacillus subtilis or Escherichia coli), or ASW. After $2 \mathrm{~h}$ incubations in ASW at $15^{\circ} \mathrm{C}$, the MGTs were processed and examined. The epithelium consistently detached from isolated MGTs injected with either species of Vibrio, but not from MGTs injected with non-pathogenic bacteria or ASW. Because the MGT epithelium secretes the peritrophic membrane, loss of the epithelium eliminates 2 layers that may restrict penetration of ingested pathogens into the shrimp body and may disrupt the osmoregulatory function of the MGT. A second finding was that fixed, large-granule hemocytes associated with the basal lamina degranulated in the presence of the 2 species of Vibrio, but not with the non-pathogenic bacteria or ASW. These blood cells may help fight specific bacteria penetrating the MGT.
\end{abstract}

KEY WORDS: Shrimp $\cdot$ Vibriosis $\cdot$ Midgut trunk $\cdot$ Hemocytes

\section{INTRODUCTION}

Vibriosis is a bacterial disease responsible for mortality of cultured shrimp worldwide (Lightner \& Lewis 1975, Adams 1991, Lavilla-Pitogo et al. 1998, Chen et al. 2000). Outbreaks may occur when environmental factors trigger the rapid multiplication of bacteria already tolerated at low levels within shrimp blood (Sizemore \& Davis 1985), or by bacterial penetration of host barriers. The exoskeleton provides an effective physical barrier to pathogens trying to penetrate the external surface of crustaceans, as well as the foregut and hindgut. However, Vibrio spp. are among the chitino- clastic bacteria associated with shell disease (Cook \& Lofton 1973) and may enter through wounds in the exoskeleton or pores (Jiravanichpaisal \& Miyazaki 1994, Alday-Sanz et al. 2002). The gills may appear susceptible to bacterial penetration because they are covered by a thin exoskeleton (Taylor \& Taylor 1992), but their surfaces are cleaned by the setobranchs (Bauer 1998). The midgut, composed of the digestive gland (DG) and the midgut trunk (MGT, often referred to as the intestine, see Lovett \& Felder 1990), is not lined by an exoskeleton and therefore seems to be a likely site for penetration of pathogens carried in the water, food and sediment (Ruby et al. 1980, Jayabalan et al. 1982). 
Vibriosis has been experimentally induced in penaeid shrimp by either immersing shrimp in water containing bacteria (Egusa et al. 1988, Chen et al. 1992, Sung et al. 1994, Hameed 1995, Esteve \& Herrera 2000) or injecting bacteria into their musculature or hemolymph (Lightner \& Lewis 1975, Aruma 1989, de la Peña et al. 1993, Jiravanichpaisal \& Miyazaki 1994, Lee et al. 1996). These studies show that regardless of the mode of infection, heavily infected shrimp typically become lethargic, the blood loses its ability to clot, and the gills, lymphoid organ, and in particular the DG show degenerative changes. Specific morphological changes to the DG include tissue necrosis, loss of the epithelium, and infiltration of hemocytes.

This paper describes the detachment of the epithelium lining the MGT in shrimp immersed in seawater containing Vibrio parahaemolyticus and V. harveyi. Detachment of the MGT epithelium was also observed in in vitro experiments where isolated MGTs were exposed to either species of Vibrio, but not when artificial seawater (ASW) or non-pathogenic bacteria were injected into isolated MGTs. Evidence is also presented that fixed granulocytes associated with the basal lamina of the MGT contribute to the defense response by degranulating in the presence of these 2 species of Vibrio but not the non-pathogenic bacteria.

\section{MATERIALS AND METHODS}

Organisms. Penaeid shrimp Sicyonia ingentis were collected by otter trawls in $100 \mathrm{~m}$ of water off the Palos Verdes peninsula, California, USA, and maintained in aquaria with seawater at $33 \mathrm{ppt}$ and $15^{\circ} \mathrm{C}$ for at least $7 \mathrm{~d}$ prior to use. Only intermolt shrimp that had normal reddish color, vigorously swam away when prodded, and which had eaten were used in subsequent experiments. Vibrio parahaemolyticus was purchased from American Type Culture Collection (ATCC 27519), and originally came from a food poisoning incident in Lousiana, USA, involving shrimp. $V$. harveyi was provided by Dr. M. O. Martin at Occidental College, and Bacillus subtilis and Escherichia coli were purchased from Ward's Natural Science, New York (85W0228 and 85W0400). The latter bacteria were grown in liquid broth (LB) containing tryptone (Difco) $10 \mathrm{~g} \mathrm{l}^{-1}$, yeast extract (Difco) $5 \mathrm{~g} \mathrm{l}^{-1}$ and $\mathrm{NaCl} 10 \mathrm{~g} \mathrm{l}^{-1}$. Both species of Vibrio were streaked onto Tryptic Soy Agar (TSA) with $2.5 \% \mathrm{NaCl}$ and grown overnight at room temperature. Aliquots $(0.5 \mathrm{ml})$ of the bacteria in freezing media (Tryptic Soy Broth with $2.5 \% \mathrm{NaCl}$ and $20 \%$ glycerol) were frozen $\left(-70^{\circ} \mathrm{C}\right)$. For experiment with either species of Vibrio, a frozen sample was thawed, added to $10 \mathrm{ml}$ liquid broth with saline (LBS, prepared the same as LB with extra $\mathrm{NaCl} 20 \mathrm{~g} \mathrm{l}^{-1}$ ), and grown overnight at room temperature. The density of Vibrio was determined by optical density (OD) at $540 \mathrm{~nm}$. An OD value of 0.1 was shown to be equivalent to $1.0 \times 10^{8}$ colonyforming units $\mathrm{ml}^{-1}\left(\mathrm{CFU} \mathrm{ml} \mathrm{m}^{-1}\right.$ ) by counting colonies on

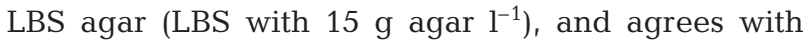
previous studies (Mikulski et al. 2000). Bacteria were pelleted by centrifugation at $1000 \times g$ for $10 \mathrm{~min}$ at $4^{\circ} \mathrm{C}$ and resuspended in $0.2 \mu \mathrm{m}$ filter-sterilized ASW (Instant Ocean, Aquarium Systems) for use.

Preliminary studies. In preliminary experiments, shrimp were immersed in individual tubs with ASW containing Vibrio parahaemolyticus or $V$. harveyi at the following concentrations: $10^{9}, 10^{7}, 10^{5}, 10^{3}$, and $10^{1} \mathrm{CFU} \mathrm{ml}{ }^{-1}$. Twenty shrimp were tested at each concentration and 20 control shrimp were isolated in individual tubs containing ASW. Likewise 20 shrimp were injected with $0.1 \mathrm{ml}$ of ASW containing $V$. parahaemolyticus or $V$. harveyi at each of the following concentrations: $10^{9}, 10^{7}, 10^{5}, 10^{3}$, and $10^{1} \mathrm{CFU}$, and then returned to individual tubs containing ASW. Control shrimp (20) received a $0.1 \mathrm{ml}$ injection of ASW. Mortality was tabulated after $7 \mathrm{~d}$. These preliminary experiments showed that the following dosages resulted in killing approximately half of the population in $7 \mathrm{~d}$ : injections of $10^{4}$ and $10^{6} \mathrm{CFU} V$. parahaemolyticus and $V$. harveyi, respectively, and immersion in ASW containing $10^{5} \mathrm{CFU} \mathrm{ml} \mathrm{ml}^{-1}$ of either species. These dosages were selected for use in the present study and are also similar to published lethal dose $\left(\mathrm{LD}_{50}\right)$ values on shrimp, although different species, different lengths of exposure, and different stages in shrimp life cycles were used (see Arume 1989, Chen et al. 1992, Jiravanichpaisal \& Miyazaki 1994, Hameed 1995, Lee et al. 1996, Goarant et al. 1998, Vandenberghe et al. 1999, Mikulski et al. 2000).

In vivo infections. Individual shrimp (mean carapace length of females $=57 \mathrm{~mm}$; males $=49 \mathrm{~mm}$ ) were maintained in plastic tubs containing $3 \mathrm{l}$ of $\mathrm{ASW}$ at $15^{\circ} \mathrm{C}$ in constant dark to simulate conditions at the collection site and checked daily. For injection experiments, 60 control shrimp were injected into the hemolymph via the 2 nd pleopod with $0.1 \mathrm{ml}$ of filter-sterilized $(0.2 \mu \mathrm{m})$ ASW. Experimental shrimp (60) received an injection of $0.1 \mathrm{ml}$ of ASW containing $10^{4} \mathrm{CFU}$ Vibrio parahaemolyticus, and a second set of 60 shrimp received an injection of $10^{6} \mathrm{CFU} V$. harveyi. For immersion experiments, control shrimp (60) were maintained in tubs containing ASW, and 2 additional sets of 60 shrimp were placed in individual tubs with 31 of ASW containing $10^{5} \mathrm{CFU} \mathrm{ml}^{-1}$ of either bacterium.

The $\mathrm{pH}$ of ASW in each tub was measured daily and levels of dissolved oxygen (DO), total ammonia, and nitrites were determined using test kits from Ward's Natural Science (\#21W9073, 21W9067, 21W9077). Tubs were not allowed to develop biological filters 
with nitrifying bacteria before experiments began so that shrimp were exposed primarily to the 2 species of Vibrio being tested. Tubs were not aerated to prevent aerosolization of pathogenic $V$. parahaemolyticus (Howard et al. 1985, Hally et al. 1995). On Day 7, surviving shrimp were categorized as either diseased or apparently healthy. Diseased shrimp typically lay on their sides and did not respond when probed, although movement of appendages, the schphognathites, and/ or heart were observed. Shrimp regarded as apparently healthy rested on their legs and moved or showed a startle response with rapid flapping of the abdomen when prodded. On Day 7, MGTs from 7 shrimp from each preparation were processed for light microscopy (LM) and transmission electron microscopy (TEM; Zeiss EM 109).

Experiments on isolated MGTs. To further assess the effects of bacteria on the MGT, $3 \mathrm{~cm}$ long sections of MGT were removed, tied off at both ends and injected with $0.1 \mathrm{ml}$ of ASW containing 1 of the following bacteria at $10^{5} \mathrm{CFU} \mathrm{ml}{ }^{-1}$ : Vibrio parahaemolyticus, V. harveyi, Bacillus subtilis, and Escherichia coli. Control preparations were injected with ASW. After a $2 \mathrm{~h}$ incubation in ASW at $15^{\circ} \mathrm{C}, 10 \mathrm{MGTs}$ from each test were fixed and processed for LM and TEM as described below. In addition to the condition of the epithelium, the layer of fixed (non-circulating), large-granule hemocytes associated with the basal lamina was examined by TEM. Specifically, the extent of degranulation in a minimum of 100 cells from each treatment was recorded as either normal (filled with electron-dense cytoplasmic granules), moderately degranulated (mixture of granules and exocytotic vesicles), or extensively degranulated (few if any granules remaining).

Tissue processing. Tissues were fixed at room temperature for $3 \mathrm{~h}$ in $3 \%$ glutaraldehyde in $0.1 \mathrm{M}$ sodium cacodylate pH 8.0 containing $3 \%$ sucrose. Following a brief rinse in buffer, tissues were post-fixed $1 \mathrm{~h}$ in $1 \%$ $\mathrm{OsO}_{4}$ in $0.1 \mathrm{M}$ sodium cacodylate, stained en bloc in $3 \%$ uranyl acetate in $0.1 \mathrm{M}$ sodium acetate buffer for $1 \mathrm{~h}$, dehydrated through a graded series of ethanol, and infiltrated and embedded in Spurr's (1969) low viscosity plastic. Thick $(0.5 \mu \mathrm{m})$ sections were stained with methylene blue, thin $(90 \mathrm{~nm})$ sections with lead citrate, and viewed by LM and TEM, respectively.

\section{RESULTS}

\section{Mortality}

Mortality was low in control shrimp; 5 of the 60 shrimp injected with ASW died by Day 7 as did 4 of the 60 shrimp immersed in ASW. Analysis of the ASW in tubs containing shrimp showed that DO typically dropped from 8 to $4 \mathrm{ppm}$ and $\mathrm{pH}$ decreased from 8.0 to 7.4 by Day 7 , while total ammonia-N and nitrite- $\mathrm{N}$ levels increased from 0 to 2.5 and $0.2 \mathrm{ppm}$, respectively.

Sixty shrimp were injected with $0.1 \mathrm{ml}$ of ASW containing $10^{4} \mathrm{CFU}$ Vibrio parahaemolyticus. Thirty-six shrimp $(60 \%)$ died by Day 4 and 4 more died by Day 7 . Of the 20 shrimp alive on Day 7, 8 were diseased and 12 appeared healthy. Sixty shrimp were injected with $0.1 \mathrm{ml}$ of ASW containing $10^{6} \mathrm{CFU} V$. harveyi. Thirtythree shrimp ( $55 \%$ ) died by Day 4 and no more died by Day 7. Of the 27 shrimp alive on Day 7,7 were considered diseased and 20 were apparently healthy.

Sixty shrimp were immersed in ASW containing $10^{5} \mathrm{CFU} \mathrm{ml}{ }^{-1}$ of Vibrio parahaemolyticus. Thirty-three ( $55 \%$ ) died by Day 4 and 5 more died by Day 7 . Of the 22 shrimp alive on Day 7, 12 were diseased and 10 appeared healthy. Sixty shrimp were immersed in $10^{5} \mathrm{CFU} \mathrm{ml}^{-1}$ of $V$. harveyi. Six (10\%) shrimp were dead by Day 4 and 23 more (48\%) died by Day 7 . Of the surviving shrimp on Day 7, 8 were diseased and 23 appeared healthy.

\section{Morphology of the MGT}

Seven days following the injection of either strain of Vibrio into shrimp hemolymph, the MGT in apparently healthy shrimp appeared normal (Fig. 1); the same as in control animals. The simple, columnar epithelium was bound to a thick $(0.8 \mu \mathrm{m})$ and wavy basal lamina and was composed of 2 types of cells as previously described (Martin \& Chiu 2003). The most numerous type of cell was elongate $(65 \mu \mathrm{m} \times 4 \mu \mathrm{m})$ with a brush border ( $5 \mu \mathrm{m}$ long), and the apical cytoplasm was filled with granules and empty-appearing vesicles suggestive of exocytosis (Fig. 2). Ovoid nuclei with patches of heterochromatin around the perimeter of the nuclear envelope occupied the middle of each cell. The basal part of each cell was filled with smooth endoplasmic reticulum. A second type of epithelial cell was ovoid, lay along the basal lamina, and contained small to large inclusions (see Figs. 1 \& 7). Outside of the basal lamina was a layer of loose connective tissue containing circular and longitudinal muscle, hemal spaces, and an outer acellular intimal layer. In diseased shrimp $7 \mathrm{~d}$ after being injected with either species of Vibrio, the MGT epithelium appeared normal in $80 \%$ of the shrimp, while in the other $20 \%$, parts or all of the epithelium was missing (see Fig. 3). Remaining epithelial cells in the latter shrimp were typically spherical (see Fig. 4).

After $7 \mathrm{~d}$ of immersion in ASW containing either species of Vibrio, the epithelium was missing in $85 \%$ of apparently healthy and $100 \%$ of the diseased shrimp (Fig. 3). Remaining cells still attached or separated 

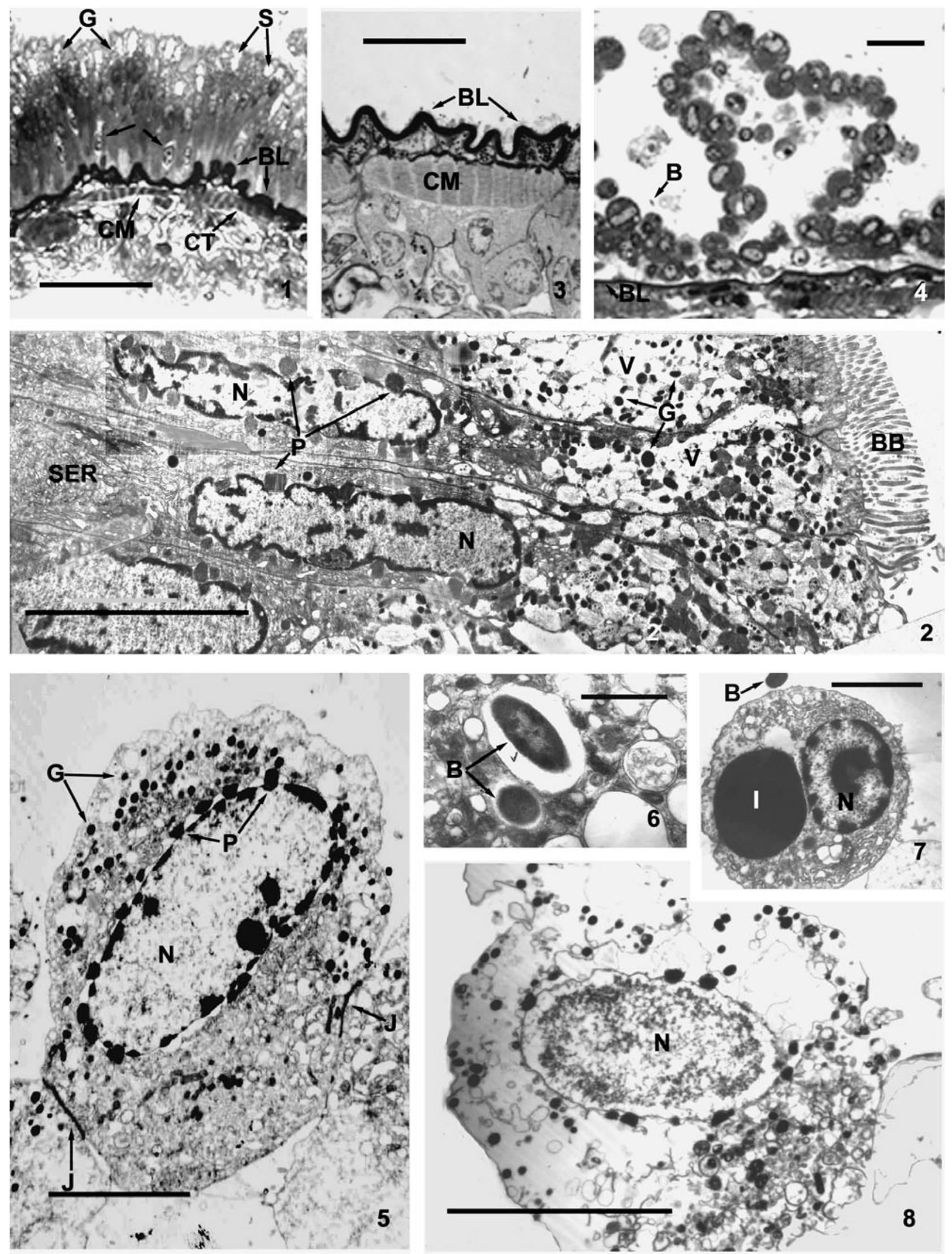
from the basal lamina were spherical and had lost their microvilli (Figs. 4 \& 5). A few spherical cells contained phagocytosed bacteria (Fig. 6), and the second type of cell containing an inclusion was occasionally seen (Fig. 7). Detached cells found further into the lumen showed signs of degeneration, with pycnotic nuclei, abundant vesicles and lysed plasma membranes (Fig. 8). No changes were observed in the basal lamina, connective tissue, and muscle layers.

\section{Isolated MGT experiments}

The morphology of the MGT appeared normal with an intact simple columnar epithelium when MGTs were removed from shrimp, tied off at both ends, injected with ASW, and incubated for $2 \mathrm{~h}$ in ASW (see Figs. 1 \& 2). Likewise, injections of ASW containing non-pathogenic bacteria (Bacillus subtilis, Escherichia coli) had no effect on the morphology of the MGT epithelium. However, when ASW containing either Vibrio parahaemolyticus or $V$. harveyi (at $10^{5} \mathrm{CFU}$ $\mathrm{ml}^{-1}$ ) was injected into the lumen of the isolated MGTs, the epithelium was missing at the end of the $2 \mathrm{~h}$ incubations in $64 \%$ of the preparations (see Fig. 3). When epithelial cells were observed, none were elongate. Instead, they were either spherical, lacking microvilli, and often attached by junctions (see Figs. 4 \& 5), or necrotic (see Fig 8).

In control preparations where isolated MGTs were injected with sterile ASW, fixed hemocytes associated with the basal lamina were filled with numerous electron-dense ovoid $(1.0 \times 0.5 \mu \mathrm{m})$ granules (Fig. 9) and a smaller number of electron-lucent vesicles $(0.4 \mu \mathrm{m})$. After $2 \mathrm{~h}$ of incubation with Vibrio parahaemolyticus or $V$. harveyi, only 18 and $29 \%$ of the fixed hemocytes, respectively, retained this morphology. Remaining hemocytes showed signs of moderate (Fig. 10; $31 \%$ $V$. parahaemolyticus, $43 \%$ V. harveyi) or extensive (Fig. 11; 51\% V. parahaemolyticus, 24\% V. harveyi) degranulation as well as clumping of heterochromatin along the nuclear envelope. The majority of granulocytes in isolated MGTs injected with either Bacillus subtilis or Escherichia coli retained the normal morphology (82 and $75 \%$ respectively) with no cells showing extensive degranulation.

\section{CONCLUSIONS}

Immersion of the penaeid shrimp Sicyonia ingentis in ASW containing either Vibrio parahaemolyticus or $V$. harveyi induced the rounding up and detachment of epithelial cells from the basal lamina of the MGT. Seven days after being injected with either species of Vibrio, epithelial cell detachment was seen in diseased but not in apparently healthy shrimp. These results suggest that Vibrio in the MGT lumen initiate epithelium detachment, whereas Vibrio injected into the hemolymph do not affect the MGT unless the infection is not controlled, and septicemia ensues. Detachment of epithelial cells was also observed in isolated pieces of MGT $2 \mathrm{~h}$ after these bacteria were injected into their lumens. Epithelial cell detachment was not seen when non-pathogenic bacteria (Escherichia coli, Bacillus subtilis) or ASW were injected into isolated MGTs for $2 \mathrm{~h}$ incubations.

Although there have been numerous studies describing morphological changes to tissues in shrimp infected with Vibrio (Lightner \& Lewis 1975, Egusa et al. 1988, Aruma 1989, Chen et al. 1992, de la Peña et al. 1993, Jiravanichpaisal \& Miyazaki 1994, Sung et al. 1994, Hameed 1995, Lee et al. 1996, Esteve \& Herrera 2000, Alday-Sanz et al. 2002), this is the first to demon-

Figs. 1 to 8. Vibrio parahemolyticus and V. harveyi infecting Sicyonia ingentis. Fig. 1. Light microscopy (LM) of the midgut trunk (MGT) wall of a healthy-appearing shrimp $7 \mathrm{~d}$ after receiving an injection of $V$. parahaemolyticus into the hemolymph. Wall looked the same as in control shrimp with an epithelium separated from a connective tissue (CT) layer by a wavy basal lamina (BL). Note that apical cytoplasm in the elongate epithelial cells contains granules (G) and spaces (S). A second type of epithelial cells (arrow) was ovoid, lay near the BL, and in some cases contained inclusions. Connective tissue layer contains circular (CM) and longitudinal muscle. Scale bar $=20 \mu \mathrm{m}$. Fig. 2. Transmission electron miscroscopy (TEM) of a normal epithelial cell from the MGT. Note the brush border (BB), G and vacuoles (V) in the apical cytoplasm, and abundant smooth endoplasmic reticulum (SER) filling the cytoplasm beneath the nucleus (N). P: nuclear pore particles. Scale bar $=10 \mu \mathrm{m}$. Fig. 3. LM of MGT from a healthy-appearing shrimp $7 \mathrm{~d}$ after being immersed in ASW containing $V$. harveyi. Note absence of the epithelial layer. Scale bar $=20 \mu \mathrm{m}$. Fig. 4. LM of MGT from a healthy-appearing shrimp $7 \mathrm{~d}$ after being immersed in ASW containing V. parahaemolyticus. Note: epithelium has detached in places from the BL and the cells have rounded up. B: bacteria. Scale bar $=10 \mu \mathrm{m}$. Fig. 5 . TEM of an epithelial cell from a healthy-appearing shrimp $7 \mathrm{~d}$ after being immersed in ASW containing $V$. parahaemolyticus. Note: cell has a circular outline and is still attached to adjacent cells by junctions (J). Although the cells lack microvilli, G and P are still present. Scale bar $=5 \mu \mathrm{m}$. Fig. 6. TEM of part of a spherical epithelial cell from a healthy-appearing shrimp $7 \mathrm{~d}$ after being immersed in ASW containing $V$. parahaemolyticus. Note: phagocytic vacuole containing a bacterium (B). Scale bar $=1.5 \mu$ m. Fig. 7. TEM of a basal cell free in the MGT lumen of a shrimp exposed to $V$. harveyi in ASW for 7 d. Note characteristic large, electron-dense inclusion (I). Scale bar $=5 \mu \mathrm{m}$. Fig. 8. TEM of a necrotic epithelial cell from the MGT of a healthy-appearing shrimp exposed to ASW containing $V$. harveyi. Scale bar $=10 \mu \mathrm{m}$ 

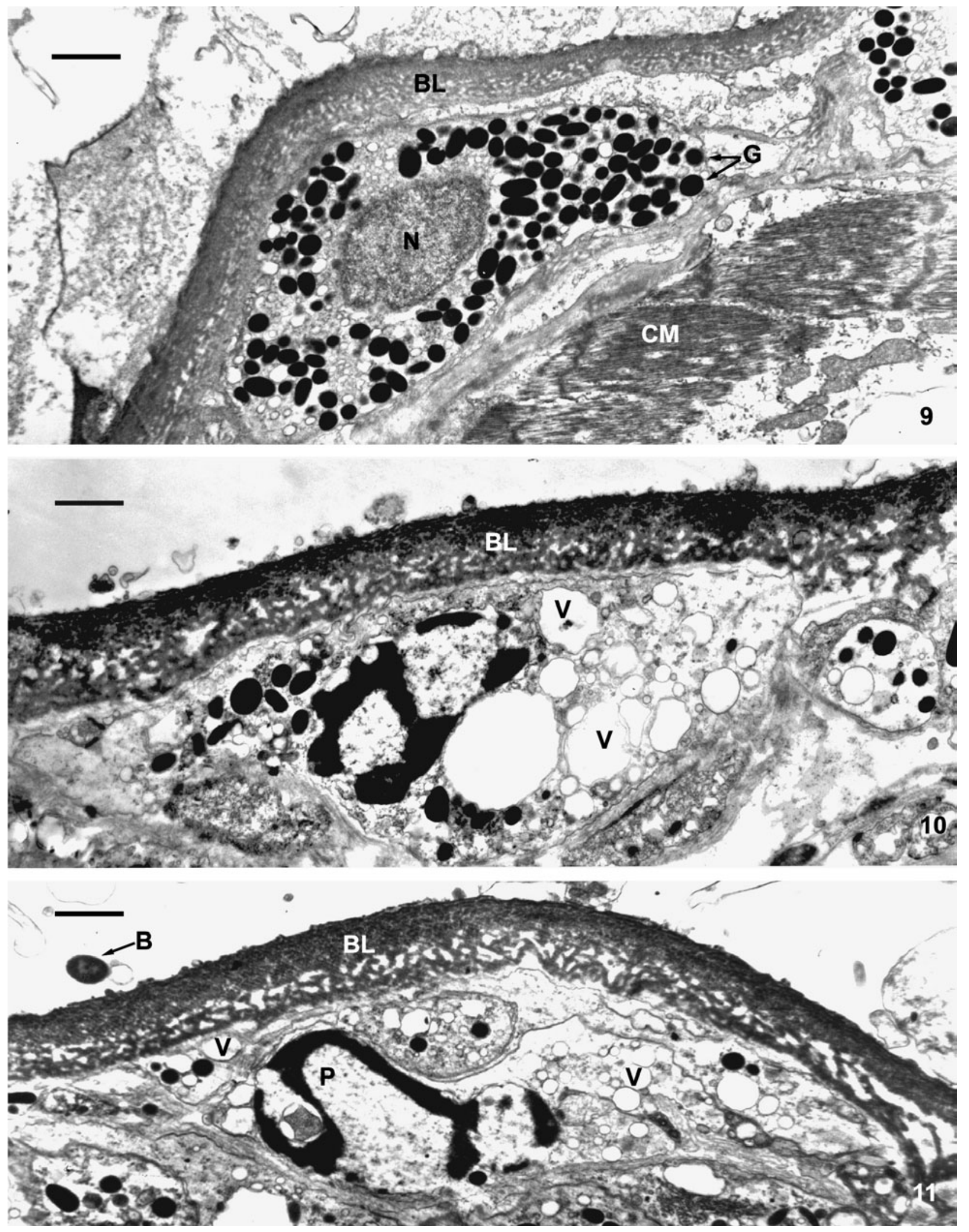
strate the detachment of the MGT epithelium. In the previous studies, only Chen et al. (1992) described changes to the MGT, i.e. an influx of hemocytes into the MGT of Penaeus monodon following exposure to $V$. harveyi. It will be important to determine if the results described in this paper are common in most penaeid shrimp or are specific to Sicyonia ingentis. Some researchers, such as Miyawaki et al. (1985), have described the separation of the epithelium (with the cells remaining elongate) as a possible fixation artifact and this may explain the apparent absence of an epithelial layer in the anterior MGT of $P$. setiferus (Lovett \& Felder 1990). We suggest that with artifactual detachment of the epithelium, the cells remain elongate and polarized, whereas when detachment is caused by toxins, the cells round up.

Could detachment of the MGT epithelium be due to poor water quality rather than the pathogenic bacteria? In our experiments, shrimp were housed in small (3 l) tubs without aeration, and during the $7 \mathrm{~d}$ experiments, the DO levels and $\mathrm{pH}$ declined as total ammonia and nitrites rose. Although there is little information on the effect of these changes on shrimp health for cold water species, like Siyonia ingentis, water quality in our experiments is within guidelines for warm water species (see Chen \& Lei 1990, Boyd $2001 \mathrm{a}, \mathrm{b})$, and mortality of our control shrimp was less than $7.5 \%$. It therefore seems probable that the elevated mortality rates in shrimp exposed to Vibrio sp. (which are well known to be pathogenic to cultured shrimp) and the detachment of the epithelium from the MGT in surviving shrimp were caused by exposure to these bacteria. Finally, our in vitro experiments also demonstrated detachment of the epithelium from the MGT only after exposure to 2 species of Vibrio.

The observation that Vibrio parahaemolyticus and $V$. harveyi affect the epithelium of the MGT in Sicyonia ingentis is not surprising considering the movement of ingested Vibrio spp. through the gut tract and previous studies on the effects of their toxins on crustaceans. $V$. proteolyticus releases a toxin that causes disassembly of zonula adherens between adjacent gut cells in the brine shrimp Artemia, the subsequent degeneration of these cells, and the penetration of the bacterium deeper into the body (Verschuere et al. 2000). Work on related species of
Vibrio include identification of toxins in $V$. cholerae that cause cell rounding by affecting the cytoskeleton (Fullner \& Mekalanos 2000), a zonula occludens toxin (Wu 1997), a lethal serine protease secreted by $V$. alginolyticus (Chen et al. 2000), and factors that affect hemostasis (Lee et al. 1999). Under natural conditions, shrimp are exposed to multiple microbes, and bacteriophages may affect the toxicity of $V$. harveyi (Ruangpan et al. 1999), and Bacillus subtilis may work as a probiotic treatment against pathogenic Vibrio (Rengpipat et al. 2003, Vaseeharan \& Ramasamy 2003). These interactions could be tested further in the in vitro system described in this paper or in recently described primary cell culture systems (Goarant et al. 2000).

A second important finding of this study is that fixed granulocytes associated with the basal lamina in Sicyonia ingentis (Martin \& Chiu, 2003) degranulated in response to the presence of Vibrio parahaemolyticus and $V$. harveyi in the lumen of the MGT. This was seen in the shrimp exposed to either species of Vibrio by injection or immersion, and quantified in the isolated MGT experiments. Previously, crustacean hemocytes had been shown to degranulate in vitro when exposed to bacteria (Söderhäll et al. 1986), and granules in hemocytes from a variety of decapod crustaceans are known to contain lysosomal enzymes, prophenoloxidase, and antibacterial compounds (Söderhäll \& Smith 1983, Martin \& Hose 1993, Khoo et al. 1999, Destoumieux et al. 2000, Bartlett et al. 2002). The hemocytes associated with the basal lamina of $S$. ingentis are well placed to fight pathogens passing into the body through the MGT. Longer-term studies are needed to determine if fixed hemocytes and other immune responses (Alday-Sanz et al. 2002, van de Braak et al. 2002) can defend the MGT until the intact epithelial layer can be restored or if death of a shrimp lacking the epithelium is inevitable. Ingested pathogens like Vibrio spp., which cause detachment of the epithelium in the MGT, can affect high mortality in $S$. ingentis by eliminating 2 layers that protect the shrimp from infections: the epithelium and the peritrophic membrane it secretes. In addition, loss of the epithelium may affect the regulation of water and ion uptake into the body (Mykles 1977, Neufeld \& Cameron 1994).

Figs. 9 to 11. Sicyonia ingentis. TEM showing the basal lamina (BL) and associated fixed granulocyte. Fig. 9. BL from an isolated midgut trunk (MGT) injected with artificial seawater (ASW)and incubated in ASW for $2 \mathrm{~h}$. Lumen of the MGT is to the top of the page. Note: granulocyte contains numerous granules $(G)$ and very few smaller electron-lucent vesicles. CM: circular muscle; N: nucleus. Scale bar $=2 \mu \mathrm{m}$. Figs. $10 \& 11$. BL in isolated MGT $2 \mathrm{~h}$ after receiving an injection of Vibrio parahaemolyticus. Note moderate (Fig. 10) and extensive (Fig. 11) degranulation of the cell, the abundance of exocytotic vesicles (V), and the pycnotic (P) nuclei. B: bacteria. Scale bars $=2 \mu \mathrm{m}$ 
Acknowledgements. We would like to thank Dr. M. O. Martin of Occidental College for supplying the Vibrio harveyi and for advice on bacterial culture, the crew of the RV 'Vantuna' for collecting the shrimp, and the Undergraduate Research Committee at Occidental College for partial support provided to N.R. and E.S.

\section{LITERATURE CITED}

Adams A (1991) Response of penaeid shrimp to exposure to Vibrio species. Fish Shellfish Immunol 1:59-70

Alday-Sanz V, Roque A, Turnbull JF (2002) Clearing mechanisms of Vibrio vulnificus biotype I in the black tiger shrimp Penaeus monodon. Dis Aquat Org 48:91-99

Aruma C (1989) Determining the lethal dose $\left(\mathrm{LD}_{50}\right)$ of Vibrio and Pseudomonas bacteria for marine shrimp. Pac Sci 43: 186

Bartlett TC, Cuthbertson BJ, Shepard EF, Chapman RW, Gross PS, Warr GW (2002) Crustins, homologues of an $11.5-\mathrm{kDa}$ antibacterial peptide from two species of penaeid shrimp, Litopenaeus vannamei and Litopenaeus setiferus. Mar Biotechnol 4:278-293

Bauer RT (1998) Gill-cleaning mechanisms of the crayfish Procambarus clarkii (Astacidea: Cambaridae): experimental testing of setobranch function. Invertebr Biol 117: 129-143

Boyd CE (2001a) Water quality standards: pH. Global Aquac Advocate 4:42-44

Boyd CE (2001b) Water quality standards: dissolved oxygen. Global Aquac Advocate 4:70-71

Chen JC, Lei SC (1990) Toxicity of ammonia and nitrite to Penaeus monodon juveniles. J World Aquac Soc 21: 300-306

Chen FR, Liu PC, Lee KK (2000) Lethal attribute of serine protease secreted by Vibrio alginolyticus strains in Kurama Prawn Penaeus japonicus. Zool Naturforsch 55:94-99

Chen SN, Huang SL, Kou GH (1992) Studies on the epizootiology and pathogenicity of bacterial infections in cultured giant tiger prawns, Penaeus monodon in Taiwan. In: Fulks W, Main KL (eds) Diseases of cultured penaeid shrimp in Asia and the United States. The Oceanic Institute, Honolulu, p 195-205

Cook DW, Lofton SR (1973) Chitinoclastic bacteria associated with shell disease in Penaeus shrimp and the blue crab. $\mathrm{J}$ Wildl Dis 9:154-159

de la Peña L, Tamaki T, Monoyama K, Nakai T, Muroga K (1993) Characteristics of the causative bacterium of vibriosis in the kuruma prawn, Penaeus japonicus. Aquaculture 115:1-12

Destoumieux D, Muñoz M, Cosseau C, Rodriguez J, Bulet P, Comps M, Bachère E (2000) Penaeidins, antimicrobial peptides with chitin-binding activity, are produced and stored in shrimp granulocytes and released after microbial challenge. J Cell Sci 113:461-469

Egusa S, Takahashi Y, Itami T, Momoyama K (1988) Histopathology of vibriosis in the Kurama prawn, Penaeus japonicus. Fish Pathol 23:59-65

Esteve M, Herrera FC (2000) Hepatopancreatic alterations in Litopenaeus vannamei (Boone, 1939) (Crustacea: Dacapoda: Penaeidae) experimentally infected with a Vibrio alginolyticus strain. J Invertebr Pathol 76:1-5

Fullner K, Mekalanos J (2000) In vivo covalent cross-linking of cellular actin by Vibrio cholerae RTX toxin. EMBO (Eur Mol Biol Organ) J 19:5315-5323

Goarant C, Regnier F, Brizard R, Marteau A (1998) Acquisition of susceptibility to Vibrio penaeicida in Penaeus stylirostris postlarvae and juveniles. Aquaculture 169: 291-296

Goarant C, Herlin J, Brigard R, Marteau AL, Martin C, Martin B (2000) Toxic factors of Vibrio strains pathogenic to shrimp. Dis Aquat Org 40:101-107

Hally RJ, Rubin RA, Fraimow HS, Hoffman-Terry ML (1995) Fatal Vibrio parahaemolyticus septicemia in a patient with cirrhosis. Digestive Dis Sci 40:1257-1260

Hameed AS (1995) Susceptibility of 3 Penaeus species to a Vibrio campbellii-like bacterium. J World Aquac Soc 26: 315-319

Howard RJ, Pessa MA, Brennamann BH, Ramphal R (1985) Necrotizing soft-tissue infections caused by marine vibrios. Surgery 98:126-130

Jayabalan N, Chandran R, Sivakumar V, Ramamoorthi K (1982) Occurrence of luminescent bacteria in sediment. Curr Sci 51:710-711

Jiravanichpaisal P, Miyazaki T (1994) Histopathology, biochemistry, and pathogenicity of Vibrio harveyi infecting Black tiger prawn, Penaeus monodon. J Aquat Anim Health 6:2735

Khoo L, Robinette DW, Noga EJ (1999) Callinectin, an antibacterial peptide from blue crab, Callinectes sapidus, hemoxytes. Mar Biotechnol 1:44-51

Lavilla-Pitogo CR, Leano EM, Paner MG (1998) Mortalities of pond-cultured juvenile shrimp Penaeus monodon associated with dominance of luminescent vibrios in the rearing environment. Aquaculture 164:337-349

Lee KK, Yu SR, Chen FR, Yang TI, Liu PC (1996) Virulence of Vibrio alginolyticus isolated from diseased tiger prawn, Penaeus monodon. Curr Microbiol 32:229-231

Lee KK, Chen YL, Lin PC (1999) Hemostasis of tiger prawn Penaeus monodon affected by Vibrio harveyi, extracellular products, and a toxic cysteine protease. Blood Cells Mol Dis 25:180-192

Lightner DV, Lewis DH (1975) A septicemic bacterial disease syndrome of penaeid shrimp. Mar Fish Rev 37:25-28

Lovett, DL, Felder DL (1990) Ontogenetic changes in enzyme distribution and midgut function in developmental stages of Penaeus setiferus (Crustacea, Decapoda, Penaeidae). Biol Bull (Woods Hole) 178:164-174

Martin GG, Chiu A (2003) Morphology of the midgut trunk in penaeid shrimp, Sicyonia ingentis, highlighting novel nuclear pore particles and fixed hemocytes. J Morphol 258:239-248

Martin GG, Hose JE (1993) Vascular elements and blood (hemolymph). In: Harrison FW, Humes AG (eds) Microscopic anatomy of invertebrates 10. Wiley-Liss, New York, p 117-146

Mikulski CM, Burnett LE, Burnett KG (2000) The effects of hypercapnic hypoxia on the survival of shrimp challenged with Vibrio parahaemolyticus. J Shellfish Res 19:301-311

Miyawaki M, Taketomi Y, Mishima S (1985) Basement membrane of the epithelium of the midgut in a freshwater shrimp, Caridina denticulata. Cytologia 50:367-372

Mykles DL (1977) The ultrastructure of the posterior midgut caecum of Pachygrapsus crassipies (Decapoda, Brachyura) adapted to low salinity. Tissue Cell 9:681-691

Neufeld DS, Cameron JN (1994) Mechanism of the net uptake of water in moulting blue crags (Callinectes sapidus) acclimated to high and low salinities. J Exp Biol 188:11-23

Rengpipat S, Tunyanun A, Fast AW, Piyatiratitivorakul S, Menasveta P (2003) Enhanced growth and resistance to Vibrio challenge in pond-reared black tiger shrimp Penaeus monodon fed a Bacillus probiotic. Dis Aquat Org 55:169-173

Ruangpan L, Danayadol Y, Direkbusarakom S, Siurairastana S, Flegel TW (1999) Lethal toxicity of Vibrio harveyi to 
cultivated Penaeus monodon induced by a bacteriophage. Dis Aquat Org 35:195-201

Ruby EG, Greenberg EP, Hastings JW (1980) Planktonic marine luminous bacteria: species distribution in the water column. Appl Environ Microbiol 39:302-306

Sizemore RK, Davis JW (1985) Source of Vibrio spp. found in the hemolymph of the blue crab Callinectes sapidus. J Invertebr Pathol 46:109-110

Söderhäll K, Smith VJ (1983) Separation of the haemocyte populations of Carcinus maenas and other marine decapods, and prophenoloxidase distrubution. Dev Comp Immunol 7:229-239

Söderhäll K, Smith VJ, Johansson MW (1986) Exocytosis and uptake of bacteria by isolated haemocyte populations of 2 crustaceans: evidence for cellular co-operation in the defense reactions of arthropods. Cell Tissue Res 245:43-49

Spurr A (1969) A low viscosity epoxy embedding medium for electron microscopy. J Ultrastr Res 26:31-43

Sung HH, Kou GH, Song YL (1994) Vibriosis resistance induced by glucan treatment in tiger shrimp (Penaeus monodon). Fish Pathol 29:11-17

Taylor HH, Taylor EW (1992) Gills and lungs: the exchange of gases and ions. In: Harrison FW, Humes AG (eds) Micro-

Editorial responsibility: Timothy Flegel,

Bangkok, Thailand scopic anatomy of invertebrates 10. Wiley-Liss, New York, p 203-293

van de Braak CB, Botterblom $M H$, Taverne $N$, van Muiswinkel WB, Rombout JH, van der Knaap WP (2002) The roles of haemocytes and the lymphoid organ in the clearance of injected Vibrio bacteria in Penaeus monodon shrimp. Fish Shellfish Immunol 13:293-309

Vandenberghe J, Verdonck L, Robles-Arozarena R, Rivera G and 6 others (1999) Vibrios associated with Litopenaeus vannamei larvae, postlarvae, broodstock, and hatchery probionts. Appl Environ Microbiol 65:2592-2597

Vaseeharan B, Ramasamy P (2003) Control of pathogenic Vibrio spp. by Bacillus subtilis BT23, a possible probiotic treatment for black tiger shrimp Peaeus monodon. Lett Appl Microbiol 36 :83-87

Verschuere L, Heang H, Criwl G, Sorgeloos P, Verstraete (2000) Selected bacterial strains protect Artemia spp. from the pathogenic effects of Vibrio proteolyticus CW8T2. Appl Environ Microbiol 66:1139-1146

Wu Z (1997) Studies of Vibrio cholerae toxins (zonula occludens toxin and hemagglutinin/protease) and their effects on epithelial cells. Linkoping University Medical Dissertation No. 513. Linköping University, Linköping

Submitted: August 25, 2003; Accepted: March 7, 2004

Proofs received from author(s): June 15, 2004 